\title{
Effect of Light, Temperature and Water Stress on Net Photosynthesis in Two Popula- tions of Honey Mesquite
}

\author{
J.D. HANSON
}

\section{Abstract}

Net carbon dioxide assimilation rates $\left(\mathrm{P}_{\mathrm{N}}\right)$ were measured for individuals from two Texas honey mesquite populations grown under controlled water stress, temperature, and light treatments. Maximum $P_{\mathrm{N}}$ observed for the various tests ranged from 0.69 to $0.82 \mathrm{mg} \bullet \mathrm{m}^{-2} \mathrm{~s}^{-1}$. Net assimilation rates were significantly lower in the west Texas population than in the east Texas population under high and low water stress. Maximum $P_{\mathrm{N}}$ at $1.35 \mathrm{mmol} \cdot \mathrm{m}^{-2} \mathrm{~s}^{-1}$ photon flux density were reached under low water stress at $20^{\circ} \mathrm{C}$ and $30{ }^{\circ} \mathrm{C}$ for east and west Texas populations, respectively. The response of $P_{N}$ to light was similar to responses reported for other $C_{3}$ species; and 81 to $99 \%$ of the variability in the data was accounted for by using a hyperbolic light response model. Light use efficiency was lower for the west Texas population, and for high temperature and water stress. High temperature and water stress treatments also caused substantial decreases in the estimated theoretical maximum net assimilation rates. Finally, the light saturation point of mesquite varied depending on population and water stress.

Honey mesquite (Prosopis glandulosa Torr. var. glandulosa), a woody perennial of the Leguminosae, is adapted to a broad range of environmental conditions. It is distributed throughout much of the Southwestern United States and occurs on more than $50 \%$ of Texas rangelands (McCully 1973). Dye and Hanson (1978), Hanson et al. (1978), and Hanson and Dye (1980) have reported on photosynthetic rates and xylem pressure potentials of in situ populations of honey mesquite in west Texas. Net $\mathrm{CO}_{2}$ assimilation rates $\left(P_{N}\right)$ of east and west Texas honey mesquite populations also have been compared (Hanson 1979). These studies of in situ mesquite, however, did not test between individual plants or plant populations because of the need to monitor complete diurnal cycles of $\mathbf{P}_{\mathrm{N}}$. This study was conducted to investigate the response of $P_{\mathrm{N}}$ to changes in water stress, temperature and light for individuals from two populations of honey mesquite grown under controlled environmental conditions. Concomitantly, effects of these variables on light response curves and light saturation points were investigated.

\section{Methods and Materials}

\section{Seed Sources}

Seeds were collected from a site in west Texas and a site in east Texas to study $P_{N}$ in different populations of mesquite (Hanson 1979). Crane County, representing the west Texas population, is located in the semiarid Trans-Pecos Region of west Texas and receives an average yearly precipitation of about $32.2 \mathrm{~cm}$. Trees of the east Texas population were located in Brazos County, which is in the temperate Blackland Prairie vegetation zone and receives an

\footnotetext{
Author was research assistant, Department of Range Science, Texas A\&M University, College Station; currently range scientist, USDA, Agr. Res. Serv.. 8408 Hildreth Road, Cheyenne, Wyo. 82009.

Research reported in this paper was partially supported by an interagency contract with the University of Texas-Surface Leasing Department, University of Texas. Approved for publication by the Director, Texas Agricultural Experiment Station.
}

average yearly precipitation of about $100 \mathrm{~cm}$.

\section{Plant Material Preparation}

Seeds, collected before abcission from a range of parental plants at both field sites, were scarified with sandpaper, planted in 4-liter plastic pots at a depth of $1.25 \mathrm{~cm}$ and grown in a controlled environment chamber. Fritted clay was used instead of soil because of its high water-retaining capacity and adequate aeration (van Bayel et al. 1978). The controlled environment chamber was set on a 14-hour photoperiod to produce $0.50 \mathrm{mmol} \bullet \mathrm{m}^{-1} \mathrm{~s}^{-1}$ photon flux density (IP, cumulative light in the $0.4-0.7 \mu \mathrm{m}$ band) supplied by a combination of fluorescent and incandescent lamps. Two auxiliary 1000-Watt multivapor lamps were added to the chamber to increase the chamber $I_{P}$ to $0.60 \mathrm{mmol} \cdot \mathrm{m}^{-2} \mathrm{~s}^{-1}$ for 10 hours each day. Plants were rotated daily to eliminate variance caused by proximity to the auxiliary lights. Temperature was $30^{\circ} \mathrm{C}$ during the day and $25^{\circ} \mathrm{C}$ during the night; relative humidity was held constant at $50 \%$. Plants were watered every other day, alternating between $50 \%$ Hoagland's solution and distilled water. The mesquite seedlings grew very well and were ready for experimentation within 6-8 weeks. From the 45 plants grown of each population, 24 plants of each population were randomly selected for $\mathbf{P}_{\mathbf{N}}$ determinations.

\section{Statistical Design and Analysis}

A $2 \times 2 \times 4 \times 5$ factorial experiment arranged in a split-split plot design with three replications was used to determine environmental tolerances of $P_{N}$ from two populations of mesquite. The first classification factor represented the population effect (east and west Texas). The second factor was leaf water stress: low stress [about -0.5 macroPascals (MPa)] and high stress (about -3.0 $\mathrm{MPa})$. The third and fourth factors were chamber temperature $(20$, 25,30 , and $\left.35^{\circ} \mathrm{C}\right)$ and incident light $(0.10,0.25,0.35,0.60$, and 1.35 $\mathrm{mmol} \cdot \mathrm{m}^{-2} \mathrm{~s}^{-1}$ ). Temperature was controlled within the assimilation chamber. Light was controlled by using different layers of cheesecloth filters over a 1000-Watt multivapor la mp (Sestak et al. 1971). Water was withheld for 2 weeks from one group of plants of each population to produce high water stress (Mooney et al. 1977). Analysis was performed using standard analysis of variance techniques. Duncan's multiple range test was subsequently used to test between treatment means.

\section{Determining Assimilation Rates}

A portable, open $\mathrm{CO}_{2}$ exchange system for measuring $\mathrm{P}_{\mathrm{N}}$ on branches of woody plants was developed by Dye and Hanson (1978). The system consisted of an assimilation chamber, a ventilation and temperature control unit, a measurement and recording unit, and a power supply unit. The components allowed continuous measurement of chamber temperature, photon flux density, air flow rates into the chamber and the difference between ambient and chamber carbon dioxide concentrations. The system was modified for this study by using a $220 \mathrm{~V} \dot{\mathrm{AC}}$ motor, instead of a 10-hp gasoline engine, to drive the air conditioner compressor. 
Each potted mesquite seedling was sealed in the assimilation chamber, and the system was allowed to reach equilibrium to a predetermined temperature level. Subsequently, the five levels of $I_{P}$ were randomly administered to the test plant. About $10 \mathrm{~min}$ additional equilibration time was given for the plant to respond to the new light level once a filter was placed over the light source. Net assimilation rates, in units of $\mathrm{mg} \bullet \mathrm{m}^{-2} \mathrm{~s}^{-1}$, were calculated from the relation

$$
\mathrm{P}_{\mathrm{N}}=k \mathrm{~F} \Delta \mathrm{CO}_{2} \mathrm{~A}^{-1}
$$

where $\Delta \mathrm{CO}_{2}$ was the $\mathrm{CO}_{2}$ deficit within the chamber in ppm, F was the flow rate of air over the branch measured as liters per hour, and A was the leaf area (one side) in $\mathrm{m}^{2}$. The constant $k$ was equal to $1.79 \times 10^{-3} \mathrm{mg} \mathrm{ppm}^{-1} \mathrm{l}^{-1}$ at $25^{\circ} \mathrm{C}$ and $0.1 \mathrm{MPa}$. A photoelectric planimeter was used to estimate areas (Kemph 1976).

\section{Light Response Model}

Data were fit to a hyperbolic light response curve of the form

$$
\mathrm{P}_{\mathrm{N}}=\alpha \mathrm{I}_{\mathrm{P}} \mathrm{P}_{\max } /\left(\alpha \mathrm{I}_{\mathrm{P}}+\mathrm{P}_{\max }\right)
$$

where the parameters $P_{\max }\left(\mathrm{mg} \bullet \mathrm{m}^{-2} \mathrm{~s}^{-1}\right)$ and $\alpha\left(\mathrm{mg} \mathrm{mmol}^{-1}\right)$ were the theoretical maximum $P_{N}$ and the light use efficiency coefficient, respectively (Thornley 1976). Light saturation points for solutions of the model using means grouped 7 ways were derived using the following procedure after $\alpha$ and $\mathrm{P}_{\mathrm{N}}$ were estimated for Equation (2). Rewriting Equation (2) as

$$
I_{P}=P_{\max } P_{N} /\left[\alpha\left(P_{\max }-P_{N}\right)\right]
$$

and setting $\mathrm{P}_{\mathrm{N}}=\rho \mathrm{P}_{\max }$, the light saturation point was defined as the incident light at which

$$
\mathrm{I}_{\mathrm{P}}=\rho \mathrm{P}_{\max } /[\alpha(1-\rho)]
$$

where $\rho$ was arbitrarily set equal to $85 \%$. Thus, the light saturation point was defined as the light intensity at which $\mathrm{P}_{\mathrm{N}}$ was $85 \%$ $P_{\max }$. Data were fit to Equation (2) to evaluate differences in $\alpha$, $P_{\max }$ and light saturation point caused by temperature, site, and water stress conditions.

\section{Results and Discussion}

\section{Response of Assimilation Rates to Water Stress}

Mean $P_{N}$ for the east and west Texas mesquite seedling populations across all levels of water stress, temperature, and light, were 0.39 and $0.27 \mathrm{mg} \mathrm{CO}_{2} \mathrm{~m}^{-2} \mathrm{~s}^{-1}$, respectively (Table $1-\mathrm{A}$ ). The difference between mean $P_{N}$ for the two populations was significant (Prob $>F=0.024$ ). Mean $P_{N}$ was significantly higher for the east Texas population than for the west Texas population at low and high water stress levels. Initially, it was hypothesized that $P_{N}$ of the west Texas population would exceed $\mathrm{P}_{\mathrm{N}}$ of the east Texas popula- tion when the populations were subjected to high water stress [ $\mathrm{H}_{0}$ : $P_{N}($ west $)>P_{N}$ (east) at high water stress] because the west Texas population originated from a drier region. Data lead to rejection of this hypothesis for the seedlings investigated, therefore it seems plants of the west Texas population may have developed resistance to harsh environmental conditions at the expense of high $P_{N}$.

Pooling data from both populations, assimilation rates of mesquite were reduced from 0.42 to $0.24 \mathrm{mg} \mathrm{m}^{-2} \mathrm{~s}^{-1}$ when the plants were subjected to high water stress conditions (Table 1-A). This $42 \%$ reduction was highly significant (Prob $>F=0.005$ ). A plausible cause of the lower $\mathrm{P}_{\mathrm{N}}$ for highly stressed plants was reduced photochemical activity (Nir and Poljakoff-Mayber 1967, Hanson and Dye 1980). The reduced activity could result from a lack of $\mathrm{CO}_{2}$ at the binding sites of the carboxylating enzyme, thereby implicating stomatal reaction to water stress as a factor limiting carbon assimilation.

\section{Response of Assimilation Rates to Temperature}

The $35^{\circ}$ treatment significantly reduced net assimilation rates as compared with the mean $P_{N}$ of $0.38 \mathrm{mg} \cdot \mathrm{m}^{-2} \mathrm{~s}^{1}$ for the other three temperatures (Table 1-A). The lack of significant differences in $\mathbf{P}_{\mathbf{N}}$ 20,25 or $30^{\circ} \mathrm{C}$ averaged across all other treatments implies a broad range of optimal temperatures and roughly coincides with an optimal soil temperature for growth of $29^{\circ} \mathrm{C}$ (Meyer et al. 1973) and with the $30^{\circ} \mathrm{C}$ optimal air temperature for $\mathrm{P}_{\mathrm{N}}$ of in situ mesquite (Hanson and Dye 1979).

$P_{\mathrm{N}}$ for the east Texas population under low water stress reached a maximum at $20^{\circ} \mathrm{C}$ and was significantly higher than $P_{N}$ at 30 and $35^{\circ} \mathrm{C}$ (Table 1-A). Mesquite from east Texas showed a similar assimilation pattern under both low and high water stress; however average assimilation rates were reduced to $0.32 \mathrm{mg} \bullet \mathrm{m}^{-2} \mathrm{~s}^{-1}$ as a result of high water stress. The west Texas population under low water stress had maximum $P_{N}$ at $25^{\circ} \mathrm{C}$. Mean $P_{N}$ for the high water stressed west Texas population was $0.16 \mathrm{mg} \bullet \mathrm{m}^{-2} \mathrm{~s}^{-1}$. There were no detectable statistical differences between temperature treatment means for the high water stressed Texas population.

At photon flux densities of $1.35 \mathrm{mmol} \cdot \mathrm{m}^{-2} \mathrm{~s}^{-1}$ and under low water stress conditions, maximum $P_{N}$ were reached at 20 and $30^{\circ} \mathrm{C}$ for the east and west Texas populations, respectively (Table 1-B). Maximum assimilation rates were comparable to maximum $P_{N}$ reported for in situ mesquite $\left(0.79 \mathrm{mg} \bullet \mathrm{m}^{-1} \mathrm{~s}^{-1}\right.$ ) (Dye and Hanson 1978). Assimilation rates over the 20 to $30^{\circ} \mathrm{C}$ temperature range were reduced $39 \%$ and $52 \%$ for the east and west Texas populations, respectively, when mesquite was subjected to high water stress. This showed a greater tendency of the east Texas population to withstand high moisture stress at optimal temperatures.

Response of Assimilation Rates to Photon Flux Density

\begin{tabular}{|c|c|c|c|c|c|c|c|c|}
\hline \multirow{3}{*}{$\begin{array}{l}\text { Temperature } \\
\text { (C) }\end{array}$} & & \multicolumn{3}{|c|}{ East Texas Population' } & \multicolumn{3}{|c|}{ West Texas Population } & \multirow[b]{3}{*}{ Mean } \\
\hline & & \multicolumn{2}{|c|}{ Stress Level } & \multirow[b]{2}{*}{ Mean } & \multicolumn{2}{|c|}{ Stress Level } & \multirow[b]{2}{*}{ Mean } & \\
\hline & & Low & High & & Low & High & & \\
\hline \multicolumn{9}{|c|}{ A. Average Photon Flux Density } \\
\hline 35 & & $0.13 \mathrm{~h}$ & $0.19 \mathrm{fgh}$ & $0.16 \mathrm{k}$ & 0.29 defg & $0.09 \mathrm{~h}$ & $0.19 \mathrm{k}$ & $0.18 \mathrm{~s}$ \\
\hline 30 & & $0.48 \mathrm{bc}$ & $0.36 \mathrm{~cd}$ & $0.42 \mathrm{i}$ & $0.39 \mathrm{~cd}$ & $0.19 \mathrm{fgh}$ & $0.29 \mathrm{j}$ & $0.35 \mathrm{t}$ \\
\hline 25 & & $0.57 \mathrm{ab}$ & $0.41 \mathrm{~cd}$ & $0.49 \mathrm{i}$ & $0.47 \mathrm{bc}$ & $0.16 \mathrm{gh}$ & $0.32 \mathrm{j}$ & $0.40 \mathrm{t}$ \\
\hline 20 & & $0.68 \mathrm{a}$ & $0.32 \mathrm{def}$ & $0.50 \mathrm{i}$ & $0.34 \mathrm{cde}$ & $0.21 \mathrm{efgh}$ & $0.28 \mathrm{j}$ & $0.39 \mathrm{t}$ \\
\hline & Mean & $0.47 x$ & $0.32 \mathrm{y}$ & & $0.37 \mathrm{y}$ & $0.16 \mathrm{z}$ & & \\
\hline \multicolumn{9}{|c|}{ B. $1.35 \mathrm{mmol} \mathrm{m}^{-2} \mathrm{~s}^{-1}$ Photon Flux Density } \\
\hline 35 & & $0.19 \mathrm{qr}$ & $0.22 \mathrm{qr}$ & & 0.43 no & $0.14 \mathrm{r}$ & & \\
\hline 30 & & 0.721 & $0.49 \mathrm{mn}$ & & 0.751 & 0.34 op & & \\
\hline 25 & & 0.781 & $0.51 \mathrm{mn}$ & & 0.691 & $0.29 \mathrm{pq}$ & & \\
\hline 20 & & 0.821 & 0.40 nop & & $0.59 \mathrm{~m}$ & $0.34 \mathrm{op}$ & & \\
\hline
\end{tabular}

Mean responses of mesquite $P_{N}$ to light were similar to responses

Table 1. Net assimilation rates $\left(\mathrm{mg} \cdot \mathrm{m}^{-2} \mathrm{~s}^{-1}\right)$ for two populations of mesquite grown under controlled environmental conditions: A. averaged across all light levels; and B. at $1.35 \mathrm{mmol} \mathrm{m} \mathrm{s}^{-1} \mathrm{~s}^{-1}$ photon flux density, measured at various levels of temperature and water stress.

Means followed by the same letter do not differ significantly $(P=0.05)$. 
Table 2. Response of $P_{N}\left(\mathrm{mg} \cdot \mathrm{m}^{-2} \mathrm{~s}^{-1}\right)$ to five photon flux densities at various temperatures, for two Texas populations of honey mesquite and at two water stress levels.

\begin{tabular}{|c|c|c|c|c|c|}
\hline \multirow{2}{*}{$\begin{array}{l}\text { Photon flux density } \\
\left(\mathrm{mmol} \mathrm{m} \mathrm{m}^{-1}\right)\end{array}$} & \multicolumn{5}{|c|}{ Temperaturel } \\
\hline & 35 & 30 & 25 & 20 & Mean \\
\hline 1.35 & $0.24 \mathrm{gh}$ & 0.57 a & $0.57 \mathrm{a}$ & $0.54 \mathrm{a}$ & $0.48 \mathrm{r}$ \\
\hline 0.60 & $0.21 \mathrm{ghi}$ & $0.44 \mathrm{bc}$ & $0.48 \mathrm{~b}$ & $0.44 b c$ & $0.39 \mathrm{~s}$ \\
\hline 0.35 & $0.17 \mathrm{ij}$ & $0.31 \mathrm{f}$ & $0.40 \mathrm{~cd}$ & $0.38 \mathrm{de}$ & $0.32 \mathrm{t}$ \\
\hline 0.25 & $0.15 \mathrm{jk}$ & $0.24 \mathrm{gh}$ & $0.33 \mathrm{ef}$ & $0.33 \mathrm{ef}$ & $0.26 \mathrm{u}$ \\
\hline \multirow[t]{3}{*}{0.10} & $0.10 \mathrm{k}$ & $0.19 \mathrm{hij}$ & 0.22 ghi & $0.26 \mathrm{~g}$ & $0.19 \mathrm{v}$ \\
\hline & \multicolumn{2}{|c|}{ Population } & \multicolumn{2}{|c|}{ Stress Level } & \\
\hline & East & West & Low & High & \\
\hline 1.35 & $0.50 \mathrm{a}$ & $0.45 \mathrm{~b}$ & $\overline{0.62 \mathrm{r}}$ & $0.34 \mathrm{u}$ & \\
\hline 0.60 & $0.45 \mathrm{~b}$ & $0.34 \mathrm{~d}$ & $0.50 \mathrm{~s}$ & $0.28 \mathrm{vw}$ & \\
\hline 0.35 & $0.38 \mathrm{c}$ & $0.25 \mathrm{e}$ & $0.39 \mathrm{t}$ & $0.24 \mathrm{x}$ & \\
\hline 0.25 & $0.34 \mathrm{~d}$ & $0.18 \mathrm{f}$ & $0.32 \mathrm{uv}$ & $0.20 \mathrm{y}$ & \\
\hline 0.10 & $0.27 \mathrm{~d}$ & $0.12 \mathrm{~g}$ & $0.26 \mathrm{wx}$ & $0.13 \mathrm{z}$ & \\
\hline
\end{tabular}

'Means followed by the same letter do not differ significantly $(P=0.05)$.

reported for other $C_{3}$ plants (Devlin and Barker 1971). In general $P_{N}$ increased rapidly with initial, small increases in photon flux density. However, large increases in light resulted in small increases in $P_{N}$ as radiation continued to increase (Table 2).

Response of $P_{\mathrm{N}}$ at 20,25 and $30^{\circ} \mathrm{C}$, across population and water stress treatments, did not differ significantly at the 1.35 and 0.60 $\mathrm{mmol} \bullet \mathrm{m}^{-2} \mathrm{~s}^{-1}$ (Table 2). However, $\mathrm{P}_{\mathrm{N}}$ did differ among these temperatures at other light levels and tended to be lower at $30^{\circ} \mathrm{C}$ than at 20 to $25^{\circ} \mathrm{C}$. Net assimilation rates were significantly lower at $35^{\circ} \mathrm{C}$ than at any other temperature used for all light levels. Also, the east Texas population had higher $P_{N}$ than the west Texas population at all light levels (Table 2). Finally, high water stress reduced $P_{\mathrm{N}}$ significantly at all light levels.

\section{Light Response Curves}

Equations (2) and (4) were solved for various combinations of means to estimate the parameters $\alpha$ and $P_{\max }$ and to calculate the light saturation point of the hyperbolic model (Table 3). The $r^{2}$ values for all solutions of the model were high. Therefore, Equation (2) seemed to be a reasonable mathematical model.

Solution 1 used the mean $P_{\mathrm{N}}$ across all treatments for each light level. The value of $\alpha$ was $3.01 \mathrm{mg} \bullet \mathrm{mmol}^{-1}$ implying a high light use efficiency. The light saturation point for Solution 1 was $0.90 \mathrm{mmol}$ - $\mathrm{m}^{-2} \mathrm{~s}^{-1}$. Solution 2 used the mean of $\mathrm{P}_{\mathrm{N}}$ across populations and water stress levels for treatments at 20,25 , and $30^{\circ} \mathrm{C}$ at each light level. The solution of this model compared closely with Solution 1 except for a slightly higher $P_{\max }$. Means of $P_{N}$ across population and water stress treatments at $35^{\circ} \mathrm{C}$ at each light level were used for Solution 3. The high temperature solution had a reduced $\alpha$ and $P_{\max }$ reflecting a decreased efficiency in light driven $\mathrm{CO}_{2}$ conversion and a lower photosynthetic capability, respectively.

Solutions 4 and 5 compared the light response curves for east and west Texas populations across temperature and water stress treatments. The most obvious difference was reduced light use efficiency in west Texas population. Theoretical maximum $P_{N}$ for the two populations was approximately the same. Therefore, the west Texas population required more light than the east Texas population to fix the same amount of $\mathrm{CO}_{2}$. This was exemplified by a $250 \%$ greater light saturation point for the west Texas population. In fact, the light saturation point for the west Texas population $\left(1.78 \mathrm{mmol} \bullet \mathrm{m}^{-2} \mathrm{~s}^{-1}\right)$ was never reached since the maximum photon flux density used was as only $1.35 \mathrm{mmol} \cdot \mathrm{m}^{-2} \mathrm{~s}^{-1}$.

The last two solutions of the model compared the light response curves for low and high water stress conditions. Mesquite under high water stress had a lower $\alpha$ and $\mathrm{P}_{\max }$ than mesquite under low water stress. Thus, high water stress conditions affected $P_{N}$ in a manner similar to elevated temperatures.

By using these fitted models the light use efficiency of mesquite was shown to be severely reduced by high temperature and water stress and by the site of seed collection. Theoretical maximum $\mathrm{P}_{\mathrm{N}}$ was decreased by $52 \%$ and $35 \%$ because of high temperature and water stress treatments, respectively.

The light saturation point is known to differ between species. Within a species it has been suggested to be a function of ambient $\mathrm{CO}_{2}$ concentration (Brun and Cooper 1967). These data suggest that the light saturation point for mesquite varies because of temperature, population, and water stress.

\section{Conclusion}

Perhaps the most intcresting information gained from this study was the significant difference in $P_{N}$ between east and west Texas populations. Hypothetically, the west Texas plants should have performed better than the east Texas plants when subjected to high water stress. However, plants from the west Texas population had lower photosynthetic rates than east Texas plants under high and low water stress levels. This is an interesting ecotypic adaptation since west Texas plants developed under high stress conditions.

Table 3. Coefficients and $r^{2}$ values for various groups of treatment means fit to Equation (2).

\begin{tabular}{|c|c|c|c|c|}
\hline$P_{\mathrm{N}}$ Mean ${ }^{1}$ & $r^{2}$ & $\begin{array}{c}\alpha \\
\left(\mathrm{mg} \mathrm{mmol}^{-1}\right)\end{array}$ & $\underset{\left(\mathrm{mg} \mathrm{m}^{-2} \mathrm{~s}^{-1}\right)}{\mathrm{P}_{\max }}$ & $\begin{array}{l}\text { Light saturation point } \\
\qquad\left(\mathrm{mmol} \mathrm{m}^{-2} \mathrm{~s}^{-1}\right)\end{array}$ \\
\hline 1. Light (mean) & 0.95 & 3.01 & 0.48 & 0.90 \\
\hline 2. Temperature $\left(20-30^{\circ} \mathrm{C}\right)$ & 0.81 & 3.48 & 0.54 & 0.88 \\
\hline 3. Temperature $\left(35^{\circ} \mathrm{C}\right)$ & 0.99 & 1.60 & 0.26 & 0.92 \\
\hline 4. East Texas population & 0.95 & 5.61 & 0.50 & 0.51 \\
\hline 5. West Texas population & 0.96 & 1.53 & 0.48 & 1.78 \\
\hline 6. Low stress & 0.88 & 4.38 & 0.57 & 0.74 \\
\hline 7. High stress & 0.99 & 1.98 & 0.37 & 1.06 \\
\hline
\end{tabular}

'Means are grouped according to the factor listed and across all other factors. 
These data may be usefully extrapolated to make an hypothesis concerning the effectiveness of herbicidal control in relation to photosynthetic activity for honey mesquite. Plants from the west Texas population had the same photosynthetic potential as those from the east Texas population (i.e., $P_{\max }$ was approximately equal for both populations) but in general they would not be light saturated for as long during the day because of the high light saturation point. Therefore, mesquite from the east Texas population would perhaps show more total photosynthetic activity if such activity were to be summed over an entire diurnal period. In the same manner, mesquite from the west Texas population would have less total photosynthetic activity because of the degree to which high temperature and high water stress reduced net photosynthesis of the test plants used in this study. If the success of herbicide application is proportional to the amount of photosynthetic activity, then the optimal time for herbicidal control of mesquite could be determined by estimating the photosynthetic activity of the plants to be sprayed. It then seems likely that mesquite control would depend on (1) the population to be controlled and (2) the environmental conditions, particularly water stress, existing at the time of herbicide application because photosynthetic activity of mesquite would differ under these conditions.

\section{Literature Cited}

Brun, W.A. and R.C. Cooper. 1967. Effects of light intensity and carbon dioxide concentration on photosynthetic rates of soybean. Crop Sci. 7:451-454.
Devlin, R.M., and A.V. Barker. 1971. Photosynthesis. VanNostrand Reinhold Company, New York. 304 p.

Dye, A.J., and J.D. Hanson. 1978. Photosynthetic rates of honey mesquite in semiarid grasslands. p. 411-413. In: Hyder, D.N., ed., Proc. 1st Internat. Rangeland Congr. Soc. Range Manage. Denver, Colo.

Hanson, J.D. 1979. Measuring and predicting net photosynthesis of honey mesquite (Prosopis glandulosa Torr. var.glandulosa). Ph.D. Diss. Texas A\&M Univ. College Station. 97 p.

Hanson, J.D., and A.J. Dye. 1980. Diurnal and seasonal patterns of photosynthesis of honey mesquite. Photosynthetica 14:1-7.

Hanson, J.D., A.J. Dye, and R.H. Haas. 1978. Xylem pressure potential and gas exchange phenomena of honey mesquite p. 419-421. In: Hyder, D.N., ed., Proc. lst Internat. Rangeland Congr.

Kemph, G.S. 1976. Measuring fibrous roots with a leaf area meter. J. Range Manage. 29:85-86.

McCully, W.G. 1973. Mesquite: Research and technology in perspective. In: Mesquite: Growth and development, management, economics, control, uses. Texas Agr. Exp. Sta., Texas A\&M Univ., College Station. p. 4.

Meyer, R.E., R.H. Haas, and C.W. Wendt. 1973. Interaction of environmental variables on growth and development of honey mesquite. Bot. Gaz. 134:173-178.

Mooney, H.A., O. Bjorkaman, and G.J. Collatz. 1977. Photosynthetic acclimation to temperature and water stress in the descrt shrub Larrea divaricata. Carnegie Institute of Washington Yearbook 76:328-335.

Nir, I., and A. Poljakoff-Mayber. 1967. Effect of water stress on the phot ochemical activity of chloroplasts. Nature 213:418-419.

Sestak, F., J. Catsky, and P.G. Jarvis, eds. 1971. Plant photosynthetic production: Manual of Methods. Dr. W. Junk, N.V., The Hague. 818 p.

Thornley, J.H.M. 1976. Mathematical models in plant physiology. Academic Press, New York. 318 p.

Van Bavel, C.H.M., R. Lascano, and D.R. Wilson. 1978. Water relations of fritted clay. Soil Sci. Soc. Amer. J. 12:657-659. 